Advisory Board

Dr. Krishna Kant Panthi

Gokarna P. Sharma

Dhurva Kumar Uprety

Editor-in-Chief Jeewan Prasad Thanju

Executive Editor

Dr. Don Messerschmidt

Associate Editors

Prof. Dr. Kiran Kumar Bhattarai

Dr. Rabin Shrestha

Rajendra P. Thanju

Salil Devkota

News Desk

Milan Dahal

Lalit P. Joshi

Publication Coordinator Kriti Gongal

Marketing Executive Shankar Bashyal

Sales and Subscription Executive Shovana Maharjan

Public Relation

Bidhya Kr. Shrestha

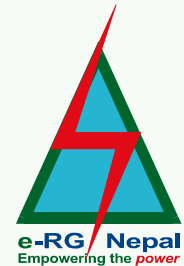

HYDRO Nepal

is published twice in a year by

Environmental Resources

Group (P) Ltd.

Contact:

P. O. Box: 15142 KPC 609

Adwait Marg, Bag Bazaar

Kathmandu, Nepal

Telephone: 977-1-4243962

email: ergnepal@gmail.com

Url: erg.com.np

C.D.O. Office Regd. 259/2064/065

Printed at:

Apollo Offset Press

Chabahil, Kathmandu

Sales in Nepal and India

Individual:

Rs. 200.00

Institutional:

Rs. 400.00

SAARC:

US\$ 10.00

Other countries: US\$ 15.00

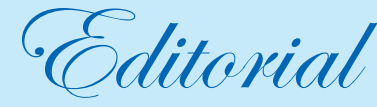

\section{Time to turn potentialities \\ into reality ...}

The Constituent Assembly Election in Nepal has clearly indicated that Nepalese want change for social transformation, and rapid development. Many countries have made miracles. For instance, Vietnam was a name associated with boat people and poverty only a few decades ago; but now, as a symbol of progress and model of fast development, it makes many people wonder. While China and India, the two giant neighbors of Nepal, are poised for phenomenal growth, Nepal cannot sit by and merely watch.

Nepal's water resources should be exploited in a revolutionary manner, on a 'war' footing. This holds the key to prosperity and poverty alleviation. There are many constraints and hurdles hampering hydropower development. All the rules, regulations and directives that hamper growth in water resources/ hydropower sectors must be amended. If the people of Nepal can change the governing system, then can't the regulations and directives be amended or changed to allow rapid development of the nation's water resources? We need also to amend our attitudes - towards revolutionary change for rapid development in Nepal.

In Nepal, the individual voices of the various water related institutions are not strong enough to be heard by the policy makers, government agencies, and the like. In this issue, we have coordinated and published a joint appeal by several water related institutions to be heard clearly in the corridors of power: for progress. All water resources related institutions must unite to raise their voices, in unison. Furthermore, from this issue onwards HYDRO Nepal will annually honor a person who has rendered outstanding services in the fields of water, energy and/or environment with an Excellence Award.

Nepalese dream for a prosperous future. The exploitation of water resources is one way to achieve this dream. Now is the time to turn huge potetialities of our country in to a reality. Nabil Bank Ltd. rightly says: "Nepal ko pani pragati ko khani" (Nepal's water is a source of national development). This could be the national slogan.

In this issue, we are also featuring articles in irrigation, water quality and other non-power sector issues. We intend to continue to expand our coverage in future issues.

Finally, we'll repeat our call from the last issue of this journal for the formation of an all powerful High Commission and to declare a Hydropower Decade (2008-18). 